\title{
Identification of a Novel Single Sequence Repeat (SSR) Marker Linked to Dwarf Plant Stature in White Yam (Dioscorea rotundata Poir.)
}

\author{
Parvathy Harikumar* and M. N. Sheela \\ Department of Crop Improvement, ICAR-Central Tuber Crops Research Institute, \\ Thiruvananthapuram, Kerala, India \\ *Corresponding author
}

\section{A B S T R A C T}

Keywords

White yam, SSR

Markers,

Dwarfness,

Trailing, Plant

architecture

Article Info

Accepted:

04 October 2019

Available Online:

10 November 2019
White Yam, a tuber crop that satisfies the caloric need of more than 300 million people around the world and due to its palatability and better yield qualities, it is widely cultivated in Indian state, Kerala. Studies showed that $30 \%$ of cost of cultivation of this crop is attributed to staking materials for trailing, and this limits the wider spread of cultivation across the country. Hence, a research program was designed to identify Single Sequence Repeat (SSR) marker linked to dwarfness in white yam, so that, it helps to develop and modify the plant architecture from trailing to dwarf type to reduce the cost of cultivation, labour charge and to increase easiness of its farming. Thirty various accessions of white yam, comprising dwarf, semi dwarf and tall varieties, were screened for genetic polymorphism using a set of 10 SSR markers. On analysis, significant polymorphisms were shown which discriminating across the genotypes evaluated. It is observed that, one SSR marker showed a unique band of $1.5 \mathrm{Kbp}$ for dwarf genotype and the sequence analysis of this product showed $90 \%$ identity to a gene from Chowghat green dwarf cutivar of Cocos nucifera, which can be used in marker assisted selection for dwarf varieties.

\section{Introduction}

Yam is an important staple crop cultivated mainly in the tropical courtiers across the globe for its underground tubers. It ranks fourth among the tuber crops in terms of the economic benefits. As per the publication of Coursey et al., (1967), the word "YAM" originated from an African word that means "to taste". Currently yam cultivation is spreads over 4.6 million ha with annual production of about 52 million tons from around 50 tropical countries (FAO, 2007). Oyenuga (1968) reported that, yam is a leading source of calories for over 300 million people in the world. And it contains higher values of protein and substantial amount of vitamins including thiamine, riboflavin and ascorbic acid and 
minerals like calcium, phosphorous and iron. It also has medicinal properties such as the steroidal sapogenins, used in the production of cortisone and synthetic steroid hormones Narula et al., (2007).

Yams are polyploid and clonally propagated plants. Greater yam, white yam, lesser yam and aerial yam are the major edible yams varieties grown in Indian subcontinent. Most species of yams are replanted and produced annually, while some species are perennial. They are harvested every season and replanted using tuber pieces to regenerate the plant. Unlike other tuber crops, the yam tubers can be stored for 4-6 months in ambient tropical conditions without significant deterioration of the nutritional properties Lebot (2009). White yam (Dioscorea rotundata Poir) is coming up as an emerging staple food crop in India and especially in the state of Kerala particularly due to for its yield potentials. One of the major concerns in yam cultivation is the requirement of staking materials for trailing and which may accounts for up to $30 \%$ of cost of cultivation of this crop, which prevents the extensive acceptability of the crop in the subcontinent. Recent studies revealed that the most critical problem in yam cultivation is the non availability of adequate staking materials and the high cost of labour for harvesting.

Indian Council of Agricultural Research Central Tuber Crops Research Institute (ICAR-CTCRI) in Kerala is the major research institute in the country for tuber crops including yam and holds a field gene bank of 1100 Dioscorea accessions including 158 white yam genotypes. Sree Dhanya is the first dwarf mutant variety of yam released by ICAR-CTCRI in the year 1993, which was suitable for planting with closer spacing without any staking. Relying on conventional breeding to develop dwarf variety in yam is time consuming due to long growth cycle, and Mignouna et al., (2007), reported that despite their economic and socio cultural importance, there is limited knowledge about the origin, phylogeny, diversity and genetics of these yams due to research neglect and several biological constraints. Therefore process of developing a new variety of yam through conventional plant breeding can take up to 25 years and such procedures are laborious and time consuming, involving several crosses over several generations and careful phenotypic selection and the linkage drag make it further difficult to achieve the desired objective.

Developments in biotechnology, especially marker assisted selection procedure has considerably shortened the time period to develop a new crop variety to 7-10 years. Advent of DNA marker technology, development of several types of molecular markers and molecular breeding strategies offered various possibilities to plant breeders and geneticists to overcome many of the problems faced during conventional breeding. In this regards, identification of DNA markers linked to key traits will make it possible to accelerate the gene transfer process. A number of molecular marker systems are now available and use of linked molecular marker would allow indirect selection for desirable traits in early segregating generations at the seedling stage independent of environmental influences.

It is also observed that DNA markers shows variations at sequence level and not influenced by environment and it will be expressed in all tissues. Some of the commonly used molecular markers are Restriction Fragment Length Polymorphism (RFLP), Random Amplification of Polymorphic DNA (RAPD), Inter Simple Sequence Repeat (ISSR), Simple Sequence Repeat (SSR), Sequence Characterized Amplified Region (SCAR), Cleaved Amplified Polymorphic Sequence (CAPS) and Sequence Tagged Sites (STS). 
With this background, the research program was designed with the primary objective to identify SSR marker linked to dwarfness in white yam through investigating tall, dwarf and semi dwarf varieties of white yam, and further which aids in propagating the varieties to the field using in-vitro methods so that the economic burden associated with cultivation of tall varieties may be minimized.

\section{Materials and Methods}

\section{Plant materials}

The plant material used in the present study were drawn from thirty accessions of tall, dwarf and semi dwarf varieties of $D$. rotundata which were maintained in the field gene bank of ICAR-CTCRI (Table 3). The samples studies were belonging to three different genotypes as mentioned and comprising of 15 tall, 14 dwarf and one semi dwarf cultivar.

\section{DNA isolation and quantification}

DNA was extracted from fresh and tender young leaves of white yam using modified protocol of Doyle \& Doyle, (1987) with suitable modifications. Quality, purity and concentration of isolated DNA samples were performed using spectrophotometer (Systronics, India) by measuring the absorbance of the samples at 260 and $280 \mathrm{~nm}$. These pooled and quantified samples were used to identify the putative SSR marker linked to the plant stature in white yam.

\section{SSR marker analysis}

The primers to be used in the present study (Table 4) that showing high polymorphic values in Dioscorea species were selected from literature study and the oligos were ordered and shipped (Integrated DNA Technologies, Inc) as lyophilized form to
ICAR-CTCRI. Polymerase chain reaction (PCR) was carried out using the components mentioned above in Thermocycler (Biorad, USA) following the protocol mentioned below (Table 1 and 2).

Further, the amplified products were separated on a $2 \%$ agarose gel along with $1 \mathrm{~Kb}$ and $100 \mathrm{bp}$ ladders to identify molecular weight of obtained bands and polymorphism and the results were photographed on a digital gel documentation and image analysis system. Only reproducible bands were scored visually and validated.

\section{Denaturing Polyacrylamide Gel Electrophoresis (PAGE) and Sequencing}

SSR primers which showed bands in agarose gel electrophoresis and that can clearly discriminate between dwarf and tall genotypes were further confirmed through PAGE, since which gives higher resolution and reproducibility. $7 \mathrm{M}$ urea denaturing PAGE (6\% polyacrylamide) was performed using Biorad Sequi- Gen® Cell $(38 \times 50 \mathrm{~cm})$ according to the manufacturer manual with heat denatured samples and detected by silver staining. After confirmation, particular band was eluted using QIAquick Gel Extraction Kit (Qiagen, USA) and were taken for sequencing using Genetic Analyser (Thermofischer Scientific, USA) and further sequence similarity search was done by BLAST analysis (NCBI, USA).

\section{Results and Discussion}

\section{DNA concentration and purity}

Medium molecular weight genomic DNA was isolated from the leaf of white yam accessions and 400ng of DNA per 100mg of tissue was obtained by the extraction performed. An absorbance ratio (A 260/280) of 1.6 to 1.8 showed in the extraction and which denotes no 
level of protein/polysaccharide contamination in the eluted DNA.

\section{Screening of SSR marker}

The amplicons obtained after the PCR for SSR analysis of 30 accessions studied using the selected 10 primers were initially resolved in two per cent agarose gel and among the 10 SSR primers used for screening, one primer namely Dab2C05 showed a band of 1478bp size which is specific for dwarf genotypes (Fig. 1).

\section{PAGE and sequencing}

All the primers used for PAGE analysis showed excellent polymorphism and no null alleles were also detected for any primers.
PAGE performed for the SSR primer Dab2C05 showed specific bands linked to dwarf genotypes. The sequence got from the eluted DNA showed electropherogram with mixed trace. On similarity search in BLASTn, got 90\% similarity with Cocos nucifera cultivar Chowghat Green Dwarf glycosyl hydrolases family 31 protein mRNA.

For preliminary screening of SSR, 14 SSR were used and out of which only 10 were selected based on their polymorphism and repeatability. The result indicated the association of the SSR marker (Dab2C05) with dwarfness in white yam since Dab2C05 showed unique band of size $1.5 \mathrm{Kbp}$ for dwarf. This finding is the first report of association of molecular markers with dwarfness in white yam.

Table.1

\begin{tabular}{|l|}
\hline PCR components \\
\hline $10 x$ reaction buffer \\
$25 \mathrm{mM} \mathrm{MgCl}$ \\
$10 \mu \mathrm{M}$ Primers \\
$10 \mathrm{mM}$ each dNTPs \\
$2 \mathrm{U}$ Taq Polymerases \\
\hline Template DNA $(50 \mathrm{ng})$ \\
\hline Total volume $(10 \mu \mathrm{L})$ \\
\hline
\end{tabular}

Table.2

\begin{tabular}{|l|l|l|l|c|}
\hline Cycling step & Temperature $\left({ }^{\circ} \mathbf{C}\right)$ & Time & Ramping rate & Cycles \\
\hline $\begin{array}{l}\text { Enzyme } \\
\text { activation }\end{array}$ & 94 & $5 \mathrm{~min}$ & & 1 \\
\hline Denaturation & 94 & $30 \mathrm{~s}$ & $\sim 2{ }^{\circ} \mathrm{C} / \mathrm{S}$ & 35 \\
\hline Annealing & 51 & $1 \mathrm{~min}$ & & 1 \\
\hline $\begin{array}{l}\text { Extension } \\
\text { Final Extension }\end{array}$ & 72 & $1 \mathrm{~min}$ & & 1 \\
\hline Hold & 72 & $8 \mathrm{~min}$ & & 1 \\
\hline
\end{tabular}


Table.3 List of white yam (D. rotundata) accessions used in the present study

\begin{tabular}{|l|l|l|}
\hline SL. No & Accession Code & Sample Name \\
\hline $\mathbf{1}$ & V1 & SREEDHANYA \\
\hline $\mathbf{2}$ & V2 & DRD 1110 \\
\hline $\mathbf{3}$ & V3 & DRD 495 \\
\hline $\mathbf{4}$ & V4 & DRD 1118 \\
\hline $\mathbf{5}$ & V5 & DRD 1835 \\
\hline $\mathbf{6}$ & V6 & DRD 1060 \\
\hline $\mathbf{7}$ & V7 & DRD 1033 \\
\hline $\mathbf{8}$ & V8 & DRD 1142 \\
\hline $\mathbf{9}$ & V9 & DRD 949 \\
\hline $\mathbf{1 0}$ & V10 & DRD 1157 \\
\hline $\mathbf{1 1}$ & V11 & DRD 1068 \\
\hline $\mathbf{1 2}$ & V12 & DRD 835 \\
\hline $\mathbf{1 3}$ & V13 & SD 15 \\
\hline $\mathbf{1 4}$ & V14 & DR 2 \\
\hline $\mathbf{1 5}$ & V15 & DR 29 \\
\hline $\mathbf{1 6}$ & V16 & DRS 47 \\
\hline $\mathbf{1 7}$ & V17 & DRS 45 \\
\hline $\mathbf{1 8}$ & V18 & DR 130 \\
\hline $\mathbf{1 9}$ & V19 & DR 17 \\
\hline $\mathbf{2 0}$ & V20 & DR 73 \\
\hline $\mathbf{2 1}$ & V21 & DRS 652 \\
\hline $\mathbf{2 2}$ & V22 & DR VIOLET \\
\hline $\mathbf{2 3}$ & V23 & DRS 36 \\
\hline $\mathbf{2 4}$ & V24 & DRS 1155 \\
\hline $\mathbf{2 5}$ & V25 & DRH 1047 \\
\hline $\mathbf{2 6}$ & V26 & DRH 657 \\
\hline $\mathbf{2 7}$ & V27 & DRH 657 A \\
\hline $\mathbf{2 8}$ & V28 & SREEPIYA \\
\hline $\mathbf{2 9}$ & V29 & SREESUBHA \\
\hline $\mathbf{3 0}$ & V30 & \\
\hline & & \\
\hline
\end{tabular}


Table.4 List of primers used in the present study

\begin{tabular}{|c|l|}
\hline Sl. No & Primer name \\
\hline $\mathbf{1 .}$ & Dab2C05 \\
\hline $\mathbf{2 .}$ & Dab2D06 \\
\hline $\mathbf{3 .}$ & Dab2E07 \\
\hline $\mathbf{4 .}$ & Da1A01 \\
\hline $\mathbf{5 .}$ & Dpr3F04 \\
\hline $\mathbf{6 .}$ & YM5 \\
\hline $\mathbf{7 .}$ & YM15 \\
\hline $\mathbf{8 .}$ & YM26 \\
\hline $\mathbf{9 .}$ & MT 13 \\
\hline $\mathbf{1 0 .}$ & MT 10 \\
\hline
\end{tabular}

Fig.1 Agarose gel electrophoresis visualization of the Dwarf genotype linked SSR marker (1.5 Kbp size) from the dwarf varieties of yam studied.

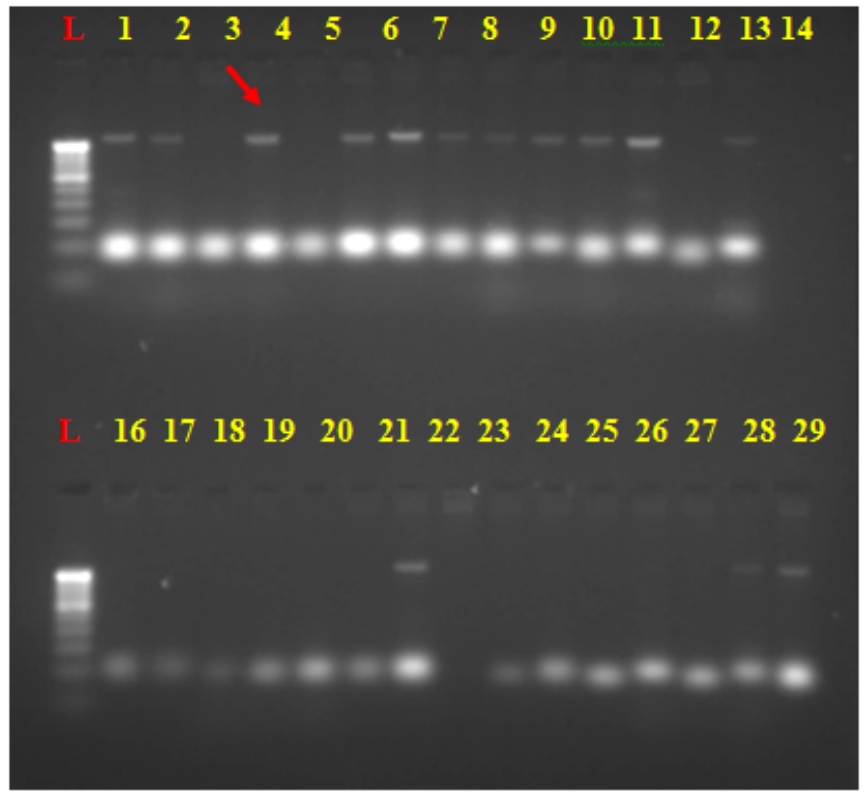

Upper Lane - Dwarf genotype

Lower Lane - Tall genotype

L-100bp ladder;1-V1;2-V2;3-

V3;4-V4;6-V12;7-V6;8-V7;9-

V8;10-V9;11-V10;12-V11;13-

V5;14-V13;15-V14;16-V29;

17-V30;18-V26;19-V27;20-

V28;21-V20;22-V16;23-;24-

V23;25-V15;26-V18;27-

V22;28-V24;29-1-V17;30-

V25

SSR Primer "Dab2C05" is screened for all the samples and on analysis, most of the dwarf varieties shows a particular band of size $1.5 \mathrm{Kbp}$ 
Whereas the molecular markers linked to plant height have been reported in other crops by few researchers. In wheat, on analyzing 21 pairs of SSR primers it is reported that 3 SSR primers namely BARC102, GWM533b and WMC623 that showed a polymorphic band linked to dwarfness and the individuals lacking the polymorphic band performed as tall genotypes (Daoura et al., 2014). In case of Brassica napus, a SCAR (Sequence Characterize Amplified Region) marker linked to dwarfness has been identified and has been developed for optimal tagging of the dwarf $B z h$ gene. Similarly the usefulness of this marker in breeding of dwarf rapeseed lines was reported by Barret et al., (1998). Restriction fragment length polymorphism (RFLP) analysis was done in case of oats (Avena sativa L.). Milach et al., (1997) reported the RFLP markers closely linked to three dwarfing genes in distinct regions of the oat genome and established that these markers contributed to plant height and can be used for characterizing new genetic sources for dwarfness in oats. In one similar study, Divashuk et al., (2013) reported reduced height genes and their importance in winter wheat cultivars grown in southern Russia.

The results on this study showed that coupling $R h t-B l e$ with $R h t 8$ or $R h t-B 1 b$ with $R h t 8$ was more successful compared with the effects of other genes or their combinations. In coconut, Rajesh et al., (2013) identified a SCAR marker for the dwarf gene derived from RAPD analysis.

Mignouna et al., (2005) studied the efficiency of different molecular markers in yams and the efficiency of RAPD, AFLP and SSR markers for the assessment of genetic relationships and for cultivar identification and discrimination among 45 West and Central African white yam cultivars belonging to 22 morphotypes/cultivar groups were established. One microsatellite markers linked to anthracnose disease tolerance in yams were available in the publication of Narina et al., (2012). Two RAPD markers namely OPW18850 and OPX15850 and which are closely linked in coupling phase with the dominant YMV- resistance locus $Y m v$-1, were identified by Mignouna et al., (2002a).

Similarly, two RAPD markers, OPI171700 and OPE6950, closely linked in coupling phase with the anthracnose resistance locus, Dcg-1, were identified by the same author (Mignouna et al., 2002b). These RAPD markers will be easier to use for indirect selection once converted into co- dominant PCR-based sequence characterized amplified regions (SCARs). In the present study on the SSR markers of white yam, the identified band specific for the dwarf genotype can be used for the marker assisted selection and development of dwarf variety of white yam for field level propagation of white yams.

\section{References}

Barret, P., Delourme, R., Foisset, N. and Delourme, R. (1998). Development of a SCAR (sequence characterised amplified region) marker for molecular tagging of the dwarf BREIZH (Bzh) gene in Brassica napus L. Theor. Appl. Genet. 97: 828-833.

Coursey, D. G. (1967). Yams. Longmans, London, U.K, 230pp.

Daoura, G. B., Chen, L., Du, Y. and Hu, G. Y. (2014). Genetic effects of dwarfing gene Rht-5 on agronomic traits in common wheat (Triticum aestivum L.) and QTL analysis on its linked traits. Field Crops Res. 156: 22-29.

Divashuk, M. G., Bespalova, L. A., Vasilyev, A. V., Fesenko, I. A., Puzyrnaya, Yu. O. and Karlov, G. I. (2013). Reduced height genes and their importance in winter wheat cultivars grown in 
southern Russia. Euphytica. 190: 137144.

FAO. (2007). FAOSTAT Database online, http//faostata.fao.org.

Lebot, V. (2009). Tropical root and tuber crops: cassava, sweet potato, yams and aroids CABI. Wallingford, Oxfordshire.

Mignouna, H. D., Abang, M. M. and Asiedu, R. (2007). Yams. In: Genome mapping and molecular breeding in plants. Volume 3, pp 271-296.

Mignouna, H. D., Abang, M.M., Onasanya, A., Agindotan, B. and Asiedu, R. (2002a). Identification and potential use of RAPD markers linked to Yam mosaic virus resistance in white yam (Dioscorea rotundata Poir.). Ann. Appl. Biol. 140: 163-169.

Mignouna, H. D., Abangh, M. M. and Fagbemi, S. A. (2005). A comparative assessment of molecular marker assays (AFLP, RAPD and SSR) for white yam (Dioscorea rotundata) germplasm characterization. Ann. Appl. Biol. 142: 269-276.

Mignouna, H.D., Abang, M. M., Onasanya, A. and Asiedu, R. (2002b). Identification and application of RAPD markers for anthracnose resistance in water yam
(Dioscorea alata). Ann. Appl. Biol. 141: 61-66.

Milach, S. C. K., Rines, H. W. and Phillips, R. L. (1997). Molecular genetic mapping of dwarfing genes in oat. Theor. Appl. Genet. 95: 783-790.

Narina, S.S., Pamela, L.M., Robert, A. \& Ali, I.M. (2012). Development of microsatellite markers for anthracnose resistance in greater yam (Dioscorea alata L.) from expressed sequence tags of heterologous crop species. J. Root Crops 38: 64-69

Narula, A., Kumar, S. and Srivastava, P. S. (2007). Genetic fidelity of in vitro regenerants, encapsulation of shoot tips and high diosgenin content in Dioscorea bulbifera L., a potential alternative source of diosgenin. Biotechnol. Lett. 29: 623-629.

Oyenuga, V.A. (1968). Nigeria food and feedstuff. University Press, Ibadan, pp 20- 27.

Rajesh,M. K., Jerard, B. A., Preethi, P., Thomas, J. R., Fayas, T. P., Rachana, K. E. and Karun, A. 2013. Development of a RAPD-derived SCAR marker associated with tall-type palm trait in coconut. Sci Hort. 150: 312-316.

\section{How to cite this article:}

Parvathy Harikumar and Sheela, M. N. 2019. Identification of a Novel Single Sequence Repeat (SSR) Marker Linked to Dwarf Plant Stature in White Yam (Dioscorea rotundata Poir.). Int.J.Curr.Microbiol.App.Sci. 8(11): 151-158. doi: https://doi.org/10.20546/ijcmas.2019.811.019 